\title{
Seasonal changes in photochemical properties of dissolved organic matter in small boreal streams
}

\author{
P. Porcal ${ }^{1,3}$, P. J. Dillon ${ }^{1}$, and L. A. Molot ${ }^{2}$ \\ ${ }^{1}$ Environmental and Resource Studies, Trent University, 1600 West Bank Drive, Peterborough, ON, K9J 7B8, Canada \\ ${ }^{2}$ Faculty of Environmental Studies, York University, 4700 Keele Street, Toronto, ON, M3J 1P3, Canada \\ ${ }^{3}$ Biology Centre of the AS CR, v.v.i., Institute of Hydrobiology, České Budějovice, Czech Republic
}

Correspondence to: P. Porcal (porcal@hbu.cas.cz)

Received: 12 March 2013 - Published in Biogeosciences Discuss.: 27 March 2013

Revised: 19 June 2013 - Accepted: 9 July 2013 - Published: 16 August 2013

\begin{abstract}
The fate of dissolved organic matter (DOM) in lakes and streams is significantly affected by photochemical transformation of DOM. A series of laboratory photochemical experiments was conducted to describe seasonal changes in photochemical properties of DOM. The stream samples used in this study originated from three different catchments in the southernmost part of the Boreal ecozone near Dorset, Ontario, Canada. A first-order kinetics equation was used to model photochemical degradation of DOM and the kinetic rate constant, $K$, was used as an indicator of photochemical properties of DOM. Kinetic rate constants from all three catchments showed a sinusoidal pattern during the hydrological year. $K$ increased steadily during autumn and winter and decreased during spring and summer with a more than 3fold range in each stream. The highest values were observed during spring melt events when DOM was flushed from terrestrial sources by high flows. The minimum rate constants were found in summer when discharge was lowest. $K$ was strongly correlated with $\mathrm{pH}$ and iron. DOM molecular weight and specific absorbance at $254 \mathrm{~nm}$ also exhibited annual cycles corresponding to the seasonal cycles of terrestrial organic matter, but the relationships between these properties and $K$ differed between seasons and may have been affected by previous exposure to solar radiation during transit from the catchment.
\end{abstract}

\section{Introduction}

Dissolved organic matter (DOM) plays several important roles in aquatic environments through its ability to absorb ultraviolet radiation, bind metals and provide microbial substrate (Chin et al., 1994; Perdue, 1998; Wetzel et al., 1995). Changes in DOM quality and quantity are likely, therefore, to have consequences for aquatic communities.

Long-term increases in DOM concentrations in lake and stream waters have been observed during the last $30 \mathrm{yr}$ across much of Europe and North America (Freeman et al., 2004; Worrall et al., 2004; Vuorenmaa et al., 2006), with much speculation about the reasons for the increase, e.g., changes in temperature and hydrology associated with climate change and a decrease in acidification (Porcal et al., 2009). Climate change models predict that higher temperatures are likely to occur over most of the boreal forest regions, and these in turn are likely to lead to changes in DOM export to and microbial DOM processing rates in lakes, which will alter concentrations of DOM and its constituents (Porcal et al., 2009) with impacts felt by biological communities. These long-term changes may have been accompanied by seasonal changes in DOM quality, for example, photoreactivity, which are just as important as long-term changes.

Our current baseline knowledge of seasonality of DOM properties is limited. However, results of some studies enable us to make some observations. Gennings et al. (2001) sampled headwater streams in the Dorset area from April to September 1997 and exposed them directly to solar radiation. They observed highest photodegradation rate constants in spring and decreasing rates during summer. Photodegradation rate constants of water from a stream near Dorset exposed to solar radiation decreased during summer (Molot et al., 2005). In these studies the photodegradation rate constants decreased during summer, but it is difficult 
to distinguish between the role of decreasing solar radiation and changing DOM properties. Brooks et al. (2007) artificially irradiated samples from several streams in Colorado that were collected during spring peak flow and summer base flow. They observed higher photodegradation in spring than in summer. Only three studies known to the authors described a seasonal trend in photochemical properties. Porcal et al. (2004) exposed samples from a tributary to acidified Plešné Lake to solar radiation at $0.5 \mathrm{~m}$ depth during the hydrological year 2000-2001. The lowest photodegradation rate constant was observed in winter while the highest photodegradation rate constant was observed in late spring. Similar observations were found by Lindell et al. (2000) in two oligotrophic lakes where the photoproduction of dissolved inorganic carbon (DIC) and the low molecular weight organic acids varied seasonally, being generally higher in winter and spring (December-May), while DOM appeared to become less photoreactive after extensive exposure to solar radiation during summer. Suhett et al. (2007) reported seasonal variation of photooxidation rates in a tropical humic lagoon and concluded that photooxidation seemed to be influenced mainly by changes in DOM photoreactivity, rather than DOM concentration, water color and sunlight incidence. These observations suggest that seasonal trends in susceptibility to photodegradation are the norm and may therefore be predictable. Clearly, models of the contribution of photochemical processes in streams, rivers, and lakes to changes in DOM quality and concentrations must recognize seasonality in, for example, photochemical rate constants, among others. However, models are limited by a lack of information on how these important DOM properties vary seasonally and why.

Long-term monitoring sites near the southern boundary of the Boreal ecozone in Ontario, Canada, where previous photochemical studies were done (Dillon and Molot 1997a; Gennings et al., 2001; Molot et al., 2005), were selected to determine possible seasonal changes in photodegradation potential of DOM transported by these streams to connected lakes during a hydrologic year, since the previous studies were limited only to spring and summer. Photochemically induced decrease in DOM concentration, a process combining direct photomineralization of DOM to $\mathrm{CO}_{2}$ (Granéli et al., 1996) and possible decrease in DOM concentration due to formation of particulate organic matter (Von Wachenfeldt et al., 2008; Porcal et al., 2010 and 2013), was measured and modeled with first-order kinetics. The relationship between calculated kinetic rate constants and DOM properties was determined during a hydrologic year in three catchments.

\section{Methods}

\subsection{Location}

Headwater streams near Dorset, Ontario, Canada, were used in this study. The three study streams (Plastic Inflow \#1
- PC1, Harp Inflow \#4 - HP4, and Dickie Inflow \#5 DE5) are located in the districts of Muskoka and Haliburton near the southern edge of the Precambrian Shield and the boundary of the Boreal ecozone. The streams are tributaries to Plastic, Harp, and Dickie lakes, long-term study sites of the impacts of long-range atmospheric transport, climate change and recreational development on water quality in forested headwater catchments and lakes (i.e., Dillon and Molot, 1997b). Table 1 presents basic characteristics of each stream and its catchment. The catchments are in the temperate forest region of the Precambrian Shield. The Harp Lake catchment is dominated by maple and birch forest that overlies glacial till-covered bedrock of biotite, hornblende gneiss and amphibolite schist. The Plastic Lake catchment has thinner soils and a predominantly coniferous forest cover. The Dickie 5 catchment is underlain by metamorphic silicate bedrock and is primarily forested with conifers although wetlands are extensive throughout. The most common soils in the study catchment are brunisolic and podzolic (Molot et al., 2005). Descriptions of physiographic and meteorological features are given in Dillon et al. (1991). The ranges of ion concentrations in each stream are presented in Table 2.

\subsection{Experimental design}

Samples were collected from September 2007 to November 2008 at 2 to 6 week intervals. Samples were collected in $20 \mathrm{~L}$ PET or HDPE carboys, previously thoroughly acid-washed and rinsed with de-mineralized water. Samples were stored in the dark and transported to a refrigerator. Before each experiment samples were filtered through a series of cartridge filters with decreasing nominal pore size from $25 \mu \mathrm{m}$ to $0.5 \mu \mathrm{m}$. Aliquots of each sample were exposed in partially filled $250 \mathrm{~mL}$ Teflon bottles to artificial solar radiation for several different time periods up to $48 \mathrm{~h}$ in duplicate or triplicate. Suntest XLS+ (Atlas GmbH, Germany) irradiation chambers equipped with a Xenon lamp were used. The spectral distribution of radiance was measured with an Ocean Optics USB2000 instrument deployed inside the irradiation chambers. We also measured the radiance inside Teflon bottles; they transmitted $44 \%$ of incident UVB and $68 \%$ of incident UVA. The intensity of irradiation was $700 \mathrm{~W} \mathrm{~m}^{-2}$. It is approximately two times higher than monthly averaged midday solar insolation for the same wavelength range, on a horizontal surface in June and approximately $30 \%$ higher than maximum outdoors irradiance under a cloudless, nonhazy sky on 21 June at our sampling location (NASA Surface meteorology and Solar Energy, http://eosweb.larc.nasa.gov). Global horizontal radiation includes the near-infrared portion of radiation, which is not measured inside the experimental irradiation chamber, hence a correction was necessary to compare global radiation to irradiation in the Suntest chambers. Global horizontal radiation data were reduced by $50 \%$ to eliminate the portion of near infrared radiation which ranges from 46 to $52 \%$ (e.g., Escobedo et al., 2011; Petty, 
Table 1. Location and basic characterization of study catchments (Dillon et al., 1991; ${ }^{*}$ Kothawala et al., 2006).

\begin{tabular}{lllrrrr}
\hline Lake & Location & Tributary & $\begin{array}{r}\text { Area } \\
\text { (ha) }\end{array}$ & $\begin{array}{r}\text { Average } \\
\text { catchment } \\
\text { grade }(\%)\end{array}$ & $\begin{array}{r}\text { Stream } \\
\text { length } \\
(\mathrm{m})\end{array}$ & $\begin{array}{r}\text { Peat } \\
(\%)\end{array}$ \\
\hline Plastic Lake & $45^{\circ} 11^{\prime} \mathrm{N}, 78^{\circ} 50^{\prime} \mathrm{W}$ & PC1 & 23.34 & 5.9 & 790 & 7.0 \\
Harp Lake & $45^{\circ} 23^{\prime} \mathrm{N}, 79^{\circ} 08^{\prime} \mathrm{W}$ & HP4 & 119.50 & 5.0 & 2040 & $8.0^{*}$ \\
Dickie Lake & $45^{\circ} 09^{\prime} \mathrm{N}, 79^{\circ} 05^{\prime} \mathrm{W}$ & DE5 & 29.98 & 1.0 & 762 & 25.4 \\
\hline
\end{tabular}

Table 2. Median, minimum and maximum concentration of individual cations and anions in streams $\left[\mathrm{mmol} \mathrm{L}^{-1}\right] . \mathrm{NH}_{4}$ and $\mathrm{NO}_{3}$ units are $\mu \mathrm{mol} \mathrm{L}^{-1}$.

\begin{tabular}{llcccccccc}
\hline & & $\mathrm{Na}$ & $\mathrm{K}$ & $\mathrm{Mg}$ & $\mathrm{Ca}$ & $\mathrm{NH}_{4}$ & $\mathrm{Cl}$ & $\mathrm{SO}_{4}$ & $\mathrm{NO}_{3}$ \\
\hline PC1 & Min & 0.02 & 0.002 & 0.01 & 0.02 & 0.53 & 0.00 & 0.00 & 0.26 \\
& Median & 0.02 & 0.003 & 0.01 & 0.03 & 0.65 & 0.01 & 0.05 & 0.32 \\
& Max & 0.04 & 0.010 & 0.04 & 0.07 & 2.08 & 0.05 & 0.06 & 0.36 \\
$\mathrm{HP} 4$ & Min & 0.03 & 0.006 & 0.02 & 0.04 & 0.12 & 0.01 & 0.04 & 0.26 \\
& Median & 0.06 & 0.008 & 0.04 & 0.05 & 0.68 & 0.03 & 0.07 & 0.88 \\
& Max & 0.25 & 0.018 & 0.06 & 0.10 & 2.88 & 0.21 & 0.08 & 1.93 \\
DE5 & Min & 0.02 & 0.001 & 0.01 & 0.02 & 0.30 & 0.01 & 0.01 & 0.22 \\
& Median & 0.03 & 0.004 & 0.02 & 0.03 & 0.54 & 0.03 & 0.01 & 0.28 \\
& Max & 0.04 & 0.015 & 0.02 & 0.05 & 1.19 & 0.09 & 0.03 & 0.35 \\
\hline
\end{tabular}

2006, and references therein) depending on atmospheric conditions, e.g., amount of water vapor.

The higher intensity of $700 \mathrm{~W} \mathrm{~m}^{-2}$ was used to reduce irradiation time and accelerate the experimental work. Previous experiments with samples from Dickie and Harp Lake catchments (dissolved organic carbon ranged from 4.8 to $40 \mathrm{~m} \mathrm{~L}^{-1}$ ) showed that photodegradation rate constants in samples irradiated under two different intensities (400 and $700 \mathrm{~W} \mathrm{~m}^{-2}$ ) for the same amount of irradiation energy did not depend on intensity but on total amount of irradiation energy (paired $t$ test, $p>0.05, n=4$ ) (Fig. 1). Samples were partly submerged in the water bath to eliminate excess heat and maintain a relatively constant sample temperature of approximately $25^{\circ} \mathrm{C}$. Dark control samples, aliquots wrapped in aluminum foil and exposed for $48 \mathrm{~h}$ to the same temperature as irradiated samples, were used to determine the influence of microbial decomposition and temperature changes on DOM.

Concentrations of dissolved organic carbon (DOC), the absorbance spectrum, $\mathrm{pH}$ and molecular weight distribution were determined on all irradiated samples, in original nonirradiated samples and in dark control samples.

\subsection{Analytical methods}

DOC (as $\mathrm{mg} \mathrm{C} \mathrm{L}^{-1}$ ) was determined by the catalytic combustion technique with nondispersive infrared detection (Shimadzu TOC- $\mathrm{V}_{\mathrm{CPH}}$, Japan). DOC content was calculated as the difference between total carbon (TC) and inorganic carbon (IC) measured after sample acidification with phospho- ric acid. The content of IC in all samples did not exceed $5 \%$ of TC (for details, see Porcal et al., 2013). Inorganic and organic standards (sodium carbonate monohydrate, $<99.5 \%$; sodium carbonate, anhydrous, $<99.5 \%$; potassium hydrogen phthalate, puriss, $<99.5 \%$; Sigma-Aldrich, USA) were used for instrument calibration as well as external standards and were analyzed at the beginning and at the end of each run to correct for possible instrumental drift. The repeatability was tested by measuring one control sample with each instrument run. The detection limit, calculated as three times standard deviation of blank samples, was $0.07 \mathrm{mg} \mathrm{CL}^{-1}$. Samples for DOC were filtered through a $0.4 \mu \mathrm{m}$ Nylon syringe filter (Mandel, Canada) prior to analysis; filters were previously rinsed with $15 \mathrm{~mL}$ of demineralized water and with $15 \mathrm{~mL}$ of sample.

Absorbance spectrum was measured from 200 to $800 \mathrm{~nm}$ in a $1 \mathrm{~cm}$ quartz cuvette (Cary $50 \mathrm{UV}$-Vis spectrophotometer, Varian). Specific UV absorbance at $254 \mathrm{~nm}\left(\mathrm{SUVA}_{254}\right)$ was calculated as the ratio of absorbance $\left(A_{254}-\right.$ absorbance at $254 \mathrm{~nm} ; 1 \mathrm{~m}$ optical path) and DOC concentration (mg C L ${ }^{-1}$ ) (Weishaar et al., 2003).

Molecular weight distribution was determined as apparent molecular weight (Köhler et al., 2002) by high-performance size exclusion chromatography (HPSEC). The value reported as an apparent molecular weight corresponds to the observed peak which represents the most abundant molecular weight in a whole sample (Köhler et al., 2002). HPSEC was performed according to Wu et al. (2003) with a liquid chromatograph (Waters 600s, USA) with a photodiode array detector (Waters 996) with detection at 215, 225, and $254 \mathrm{~nm}$. 


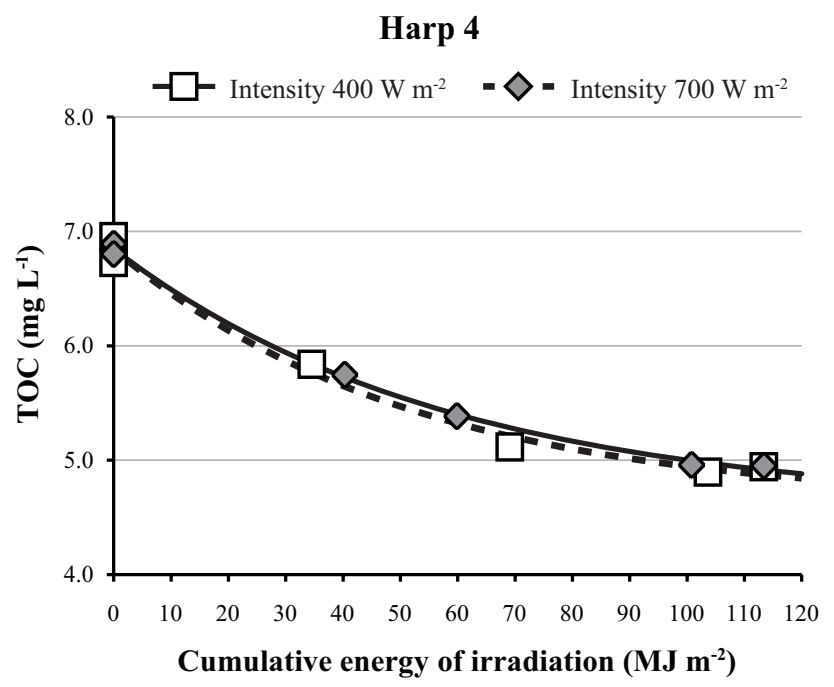

Fig. 1. The first-order kinetics equation fit with measured data at different intensities of irradiation. Cumulative irradiation energy was calculated as a product of intensity and time of irradiation.

A TSK-gel ${ }^{\circledR}$ column $(7.8 \mathrm{~mm} \times 30 \mathrm{~cm}$ and a particle size of $5 \mu \mathrm{m}$; model G2500PWXL, Tosohaas, Japan) combined with a guard column (TSK-gel ${ }^{\circledR}$ Guard PWxl, $6 \mathrm{~mm} \times 4.0 \mathrm{~cm}$, particle size $12 \mu \mathrm{m}$ ) was used for size exclusion. For each run, $100 \mu \mathrm{L}$ of sample was injected onto the column with phosphate buffer $\left(0.1 \mathrm{~mol} \mathrm{~L}^{-1} \mathrm{NaCl}, \mathrm{pH} 6.8\right)$ as an eluent, and the buffer flow rate was set at $0.5 \mathrm{~mL} \mathrm{~min}^{-1}$. The column void volume and total permeation volume of the column were determined using Blue Dextran (Sigma-Aldrich) and acetone (Sigma-Aldrich), respectively. Sodium polystyrene sulfonates were used as molecular mass calibration standards $\left(M_{\mathrm{W}} 1100,3610,4800,6500,15450\right.$, and $\left.31000 \mathrm{Da}\right)$.

Discharge was measured at calibrated V-shaped (PC1 and DE5) or rectangular (HP4) weirs at each sampling site (Devito and Dillon, 1993).

\subsection{Photodegradation rate constant}

A first-order kinetics Eqs. (1a) and (1b) was used to describe the observed decrease in DOC concentration during irradiation experiments:

$$
\frac{\partial \mathrm{DOC}}{\partial E}=-K \cdot \mathrm{DOC}
$$

and

$$
\mathrm{DOC}=\mathrm{DOC}_{0} \cdot e^{-K E},
$$

where $\mathrm{DOC}_{0}$ is the initial DOC concentration $\left(\mathrm{mg} \mathrm{C} \mathrm{L}^{-1}\right), K$ is the photodegradation rate constant $\left(\mathrm{m}^{2} \mathrm{GJ}^{-1}\right)$ and $E$ is the cumulative energy of irradiation $\left(\mathrm{GJ} \mathrm{m}^{-2}\right)$. Nonlinear regression analysis was used to fit Eq. (1) with experimental results (Brown, 2001). The minimum number of points used to fit an exponential decay curve was 4 . Experiments were terminated after being irradiated for $48 \mathrm{~h}$. The influence of extended irradiation time on calculated photodegradation rate constant was tested and did not show any significant difference in modeled photodegradation rate constants. We used the calculated rate constant, $K$, as a photochemical property of DOM.

The irradiation time of $48 \mathrm{~h}$ corresponded to approximately 11 days of average solar insolation in June at our sampling locations. Potential daily percentage decrease in DOM in streams $(\Delta)$ was calculated as a decrease in DOC concentration during one day of natural irradiation according to Eq. (2).

$\Delta=\frac{\left(\mathrm{DOC}_{0}-\mathrm{DOC}_{1}\right)}{\mathrm{DOC}_{0}} \cdot 100$,

where $\mathrm{DOC}_{0}$ is the initial DOC concentration in stream $\left(\mathrm{mg} \mathrm{C} \mathrm{L}^{-1}\right)$ and $\mathrm{DOC}_{1}$ is DOC concentration $\left(\mathrm{mg} \mathrm{C} \mathrm{L}^{-1}\right)$ after one day of exposure to natural solar radiation. $\mathrm{DOC}_{1}$ was calculated according to Eq. (3),

$\mathrm{DOC}_{1}=\mathrm{DOC}_{0} \cdot e^{-K \cdot I}$,

where $\mathrm{DOC}_{0}$ is the initial DOC concentration in stream ( $\mathrm{m} \mathrm{C} \mathrm{L}^{-1}$ ) at sampling, $K$ is the calculated photodegradation rate constant, and $I$ is the average daily insolation on a horizontal surface $\left(\mathrm{GJ} \mathrm{m}^{-2}\right)$ for given day. The average daily insolation was calculated from monthly averaged data by linear interpolation and reduced by $50 \%$ to eliminate the portion of near-infrared radiation. Monthly averaged data of insolation on a horizontal surface for the Dorset region $(22 \mathrm{yr}$ average, location $45^{\circ} 30^{\prime} \mathrm{N}, 78^{\circ} 30^{\prime} \mathrm{W}$ ) was obtained from the NASA Atmospheric Science Data Center, Surface meteorology and Solar Energy (http://eosweb.larc.nasa.gov/sse/).

Photodegradation rate constants, $K$, presented in this study were derived from DOM exposed in solar simulators to constant spectral quality and are therefore a valid measure of changes in photochemical reactivity potential. Since in situ $K$ will not vary with irradiation intensity for reasons discussed above, it will not vary with changes in canopy thickness or cloud cover unless spectral quality changes. In situ $K$ will, however, differ with time of day and year because of significant changes in spectral quality in the UV region of the solar spectrum.

The initial filtration $(0.5 \mu \mathrm{m})$ does not remove all bacteria. There is some possibility of synergistic effect of bioand photodegradation of DOC during irradiation due to formation of easily biodegradable photo-byproducts (Miller and Moran, 1997). A recent review by Ruiz-Gonzáles et al. (2013) showed variability in bacterial response during irradiation ranging from stimulation to inhibition. However, most of the reported studies irradiating with a full range of artificial UVA and UVB inhibited microbial growth, perhaps due to photoproduction of singlet oxygen and other reactive oxygen species (Zepp et al., 1977; Scully et al., 2003). Singlet oxygen is the primary agent of photooxidative stress in 
microorganisms (Glaeser et al., 2011) and high concentrations may delay consumption of readily microbially decomposable organic matter until dark conditions prevail. In our experiments, irradiation with a full range of UV was continuous, the intensity used was high, the microbial community was reduced in size via filtration and the experiment duration was short (i.e., $48 \mathrm{~h}$ is a short period of time for the remaining microbes to adapt to harsh conditions). Hence, it is reasonable to assume that the effect of residual microbial activity in filtered samples was very low and photochemical rates were not corrected for residual microbial activity.

\section{Results}

\subsection{Irradiation results}

The initial DOC concentration in all experiments decreased less than $5 \%$ in dark control samples during 48 hours of dark. The DOC concentration following $48 \mathrm{~h}$ of irradiation decreased in all streams to as low as $22 \%$ of the initial DOC concentration (the maximum loss occurred in PC1 in winter samples). The lowest measured DOC decrease of $25 \%$ was observed in HP4 samples from late summer. The ranges in DOC decreases after $48 \mathrm{~h}$ of irradiation were 31 to $75 \%, 25$ to $63 \%$, and 31 to $78 \%$ in DE5, HP4, and PC1, respectively. The highest DOC declines during irradiation were observed in spring in DE5 and HP4, and in winter in PC1. The lowest decreases were observed in all streams during summer. It cannot be assumed that observed decreases in DOC are due only to production of DIC because some of the DOC may have been removed from solution as particulate organic carbon (POC) formed by adsorbing to coagulating $\mathrm{Fe}$ and $\mathrm{Al}$ hydroxides. These metals were previously organically bound and released during irradiation (Porcal et al., 2010 and 2013).

Photodegradation rate constants calculated according to equation (1b) ranged from 2.5 to $11.1 \mathrm{~m}^{2} \mathrm{GJ}^{-1}$ in all samples with a more than 3 -fold range in each stream. In DE5 the photodegradation rate constants ranged from 3.1 to $10 \mathrm{~m}^{2} \mathrm{GJ}^{-1}$, with a median value of $5.7 \mathrm{~m}^{2} \mathrm{GJ}^{-1}$ (Fig. 2). In PC1 the range of photodegradation rate constants was from 3.1 to $11.1 \mathrm{~m}^{2} \mathrm{GJ}^{-1}$, with a median value of $7.2 \mathrm{~m}^{2} \mathrm{GJ}^{-1}$ (Fig. 3). The photodegradation rate constants in HP4 were significantly lower than in PC1 and DE5 (ANOVA, $F(2,82)=17.5, p<0.001)$, and ranged from 2.5 to $8.8 \mathrm{~m}^{2} \mathrm{GJ}^{-1}$, with a median value of $3.7 \mathrm{~m}^{2} \mathrm{GJ}^{-1}$ (Fig. 4). The goodness of fit $\left(R^{2}\right)$ of the first-order decay model with observed data ranged from 0.78 to 0.99 .

\subsection{Seasonal trends in photodegradation rate constants}

The seasonal trends in photodegradation rate constants, $K$, were similar in all three streams. The photodegradation rate constants increased during autumn and were stable during winter months. In the samples collected during the first days of snowmelt the photodegradation rate constants were sta-
Dickie 5
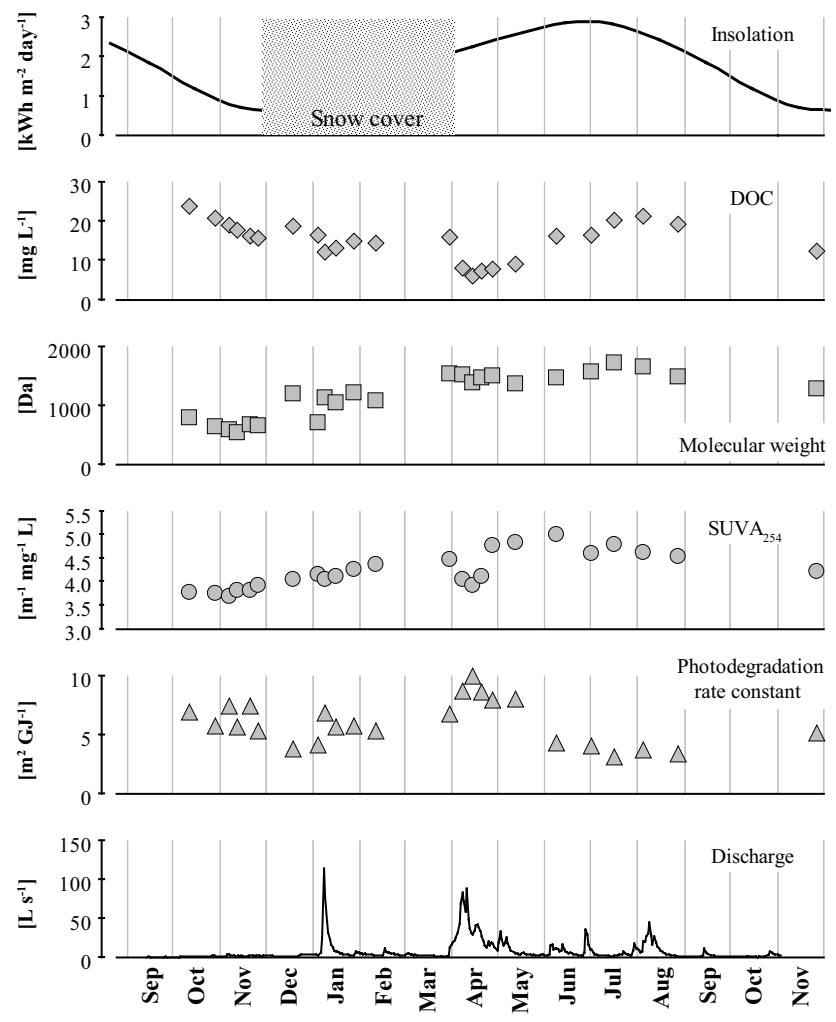

Fig. 2. Dickie 5 (DE5) tributary to Dickie Lake. Average incident insolation, DOC, apparent molecular weight, $\mathrm{SUVA}_{254}$, photodegradation rate constant and mean daily discharge during hydrological year 2007-2008.

ble and similar to winter values (Figs. 2, 3 and 4). During snowmelt and following higher spring flows, the photodegradation rate constants jumped to their maximum values and remained high for about two weeks, then sharply decreased to values lower than winter ones. The period of higher photodegradation rate constants lasted approximately one month in PC1 and HP4 and six weeks in DE5. The photodegradation rate constants continued to decrease during spring and stabilized in summer, when they reached their annual minimum. During autumn the photodegradation rate constants began to increase and reached values similar to the previous year.

Estimated potential daily percentage decreases in DOC (the potential decrease in DOC due to natural solar radiation) ranged from 1 to $8 \%$ (Fig. 5). Lower values are more likely in winter corresponding to the lowest intensity of solar radiation and will be lower still if ice and snow cover are present. The highest potential daily percentage decrease in DOC is possible in spring when the photodegradation rate constants are the highest and solar radiation is at intermediate intensities. The median and maximum potential photochemical decreases in DOC in one day were $3 \%$ and $8 \%$ in both PC1 and DE5 and $2 \%$ and $7 \%$ in HP4 (Fig. 5). 

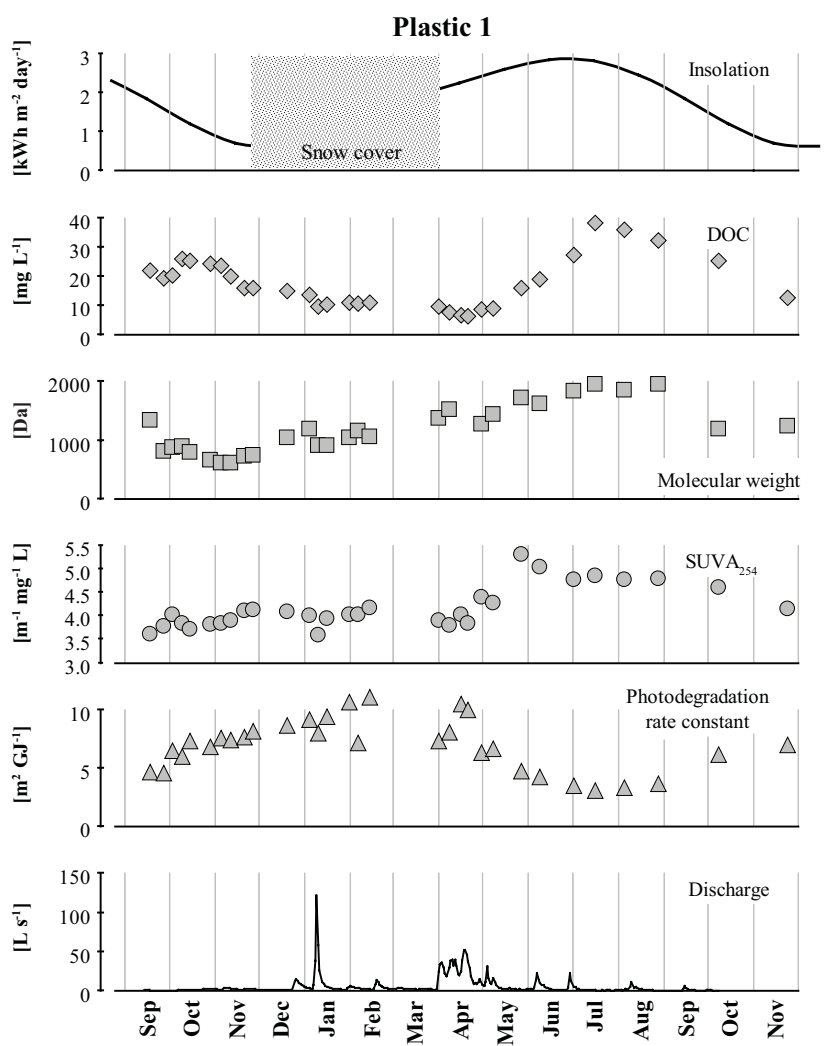

Fig. 3. Plastic $1(\mathrm{PC} 1)$ tributary to Plastic Lake. Average incident insolation, DOC, apparent molecular weight, $\mathrm{SUVA}_{254}$, photodegradation rate constant and mean daily discharge during hydrological year 2007-2008.

The seasonal trends observed in this study agree with earlier studies of photodegradation of DOM under natural solar radiation in North America (Molot and Dillon, 1997; Gennings et al., 2001; Molot et al., 2005) and Europe (Lindell et al., 2000; Porcal et al., 2004) and artificial radiation in North America (Brooks et al., 2007). Only studies of Lindell et al. (2000) and Porcal et al. (2004) examined a full year.

\subsection{DOM concentration and discharge}

The highest DOC concentration in all samples was $38 \mathrm{mg} \mathrm{L}^{-1}$ and was observed in July 2008 in PC1 at a flow rate of $0.5 \mathrm{~L} \mathrm{~s}^{-1}$; the lowest DOC concentration of $4.6 \mathrm{mg} \mathrm{L}^{-1}$ was observed in HP4 in May 2008 during the baseflow period following spring snowmelt $\left(13 \mathrm{~L} \mathrm{~s}^{-1}\right)$. The DOC concentration in $\mathrm{PC} 1$ ranged from 6.3 to $38 \mathrm{mg} \mathrm{L}^{-1}$ (Fig. 3). The DOC concentration in HP4 was lower than in PC1 and DE5 and ranged from 4.6 to $12.1 \mathrm{mg} \mathrm{L}^{-1}$ (Fig. 4). In DE5 the DOC concentration ranged from 6 to $23 \mathrm{mg} \mathrm{L}^{-1}$ (Fig. 2). The discharge in all streams was low during autumn and winter 2007. Spring melt began at the end of March 2008. The magnitude of discharge was higher in HP4 than in PC1 and DE5 because of its catchment size (Table 1), but

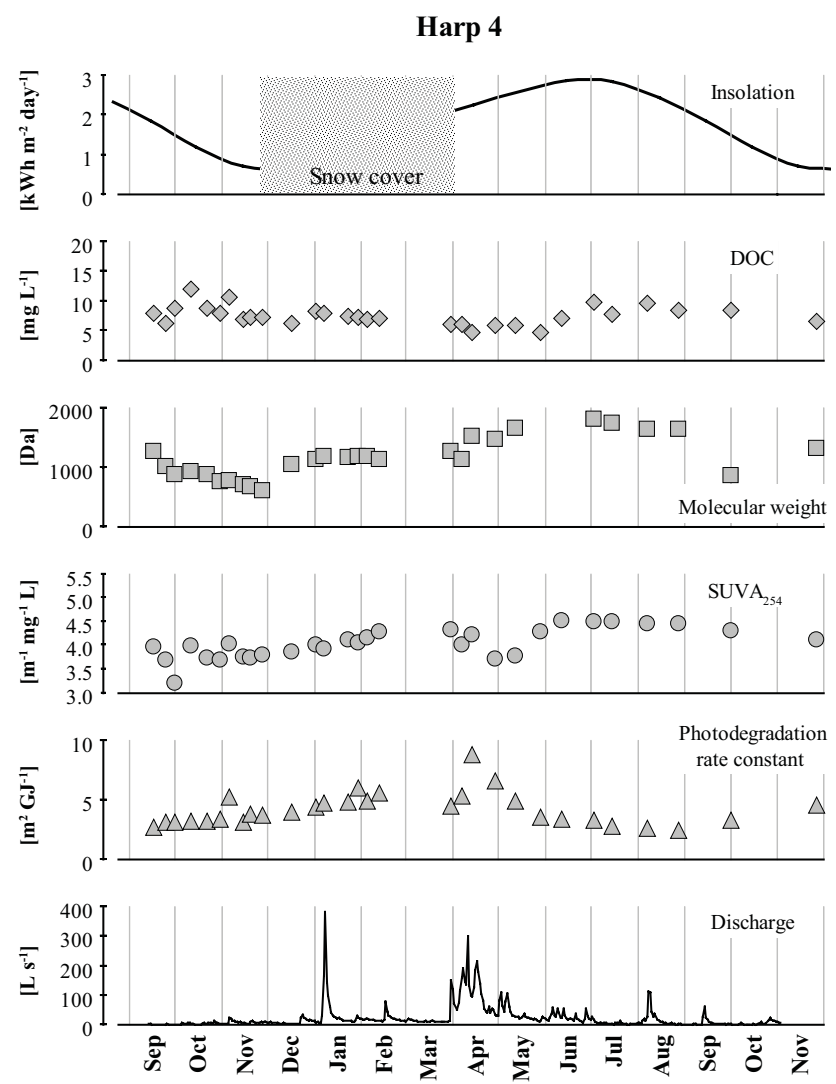

Fig. 4. Harp 4 (HP4) tributary to Harp Lake. Average incident insolation, DOC, apparent molecular weight, $\mathrm{SUVA}_{254}$, photodegradation rate constant and mean daily discharge during hydrological year 2007-2008.

the areal runoff (discharge per unit area) was comparable between HP4 and PC1 and lower at DE5. The lower discharge in DE5 was, despite its larger catchment size, likely due to its lower catchment slope (Table 1).

\subsection{Initial pH of samples}

The $\mathrm{pH}$ in DE5 ranged from 4.2 to 5.0 with median value of 4.7. The highest $\mathrm{pH}$ values in DE5 occurred during summer 2008, while the lowest values were measured in autumn 2007. In PC1 the $\mathrm{pH}$ ranged from 4.1 to 6.0 with a median value of 4.5. The highest $\mathrm{pH}$ values in $\mathrm{PC} 1$ were observed at the end of summer 2007, the lowest values during winter months. In HP4 the $\mathrm{pH}$ ranged from 5.1 to 7.0 with a median value of 6.4. The highest $\mathrm{pH}$ values were observed in late summers of 2007 and 2008. The $\mathrm{pH}$ decreased during autumn and winter until spring melt and then rose again.

\subsection{Structure of DOM: molecular weight and SUVA 254}

The structure of DOM was indirectly characterized by measurements of apparent molecular weight of DOM (Figs. 24 ), which can be used as a proxy of freshness or age of 
Potential daily photodegradation loss of DOC

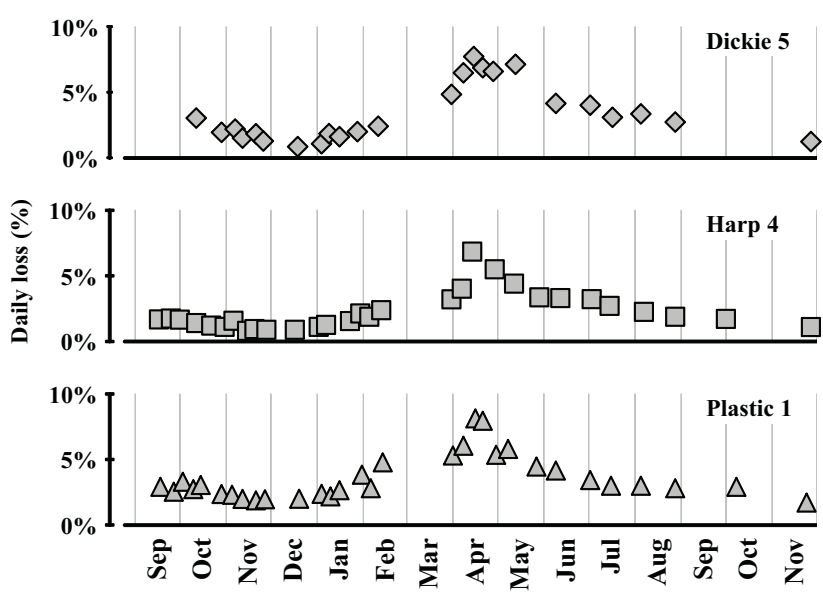

Fig. 5. Potential daily percentage decrease in DOC - calculation is based on the initial DOC concentrations, daily incident solar insolation and photodegradation rate constants determined in lab experiments (Eq. 2).

terrestrially derived organic matter (Cabaniss et al., 2005). A seasonal trend was observed in all three streams. The molecular weight decreased during late summer and beginning of autumn and then began to increase consistently until the following summer when it reached its maximum in June and began to decrease to its autumn minimum. The molecular weight ranged from 1620 to $2970 \mathrm{Da}$ with a median of $2160 \mathrm{Da}$ in PC1, from 1550 to $2730 \mathrm{Da}$ with a median of $2290 \mathrm{Da}$ in DE5, and from 1610 to $2810 \mathrm{Da}$ with a median of $2160 \mathrm{Da}$ in HP4. The correlation between $K$ and molecular weight was significant only in PC1 with $r=-0.62(n=31$, $p<0.05$ ).

The increase in molecular weight was accompanied by an increase in $\mathrm{SUVA}_{254}$, a measure of the content of aromatic groups in DOM structure (Weishaar et al., 2003), although the relationship varied among the streams. SUVA 254 decreased slightly during spring snowmelt and high flow and then returned to its previous level in late May-early June about a month before peak molecular weight occurred. The correlation between $K$ and $\mathrm{SUVA}_{254}$ in all samples was significant but weak $-0.23(n=85, p<0.05)$. In PC1 the correlation was $-0.56(n=31, p<0.05)$. No significant correlations were observed for either DE5 or HP4.

The relationship between photodegradation rate $(K)$, molecular weight and aromaticity is not straightforward. In all streams (Figs. 2-4), $K$ peaked in late April, followed by $\mathrm{SUVA}_{254}$ and then molecular weight about two months after the peak in $K$. Whatever processes lead to higher $K$ over winter also lead to higher $\mathrm{SUVA}_{254}$ and molecular weight but the increases in molecular weight and $\mathrm{SUVA}_{254}$ continued for several months after $K$ began to decrease.
We divided samples into two groups with regard to possible insolation. The first group of samples represented the time period when the catchments were entirely snow covered (from mid November 2007 to March 2008). Strong positive correlations between photodegradation rate constant, $K$, and molecular weight were observed for individual sites (PC1 $r=0.75, n=9$; HP4 $r=0.71, n=11$; DE5 $r=0.92$, $n=5 ; p<0.05$ in all cases) (Fig. 6); samples collected during high flow events (Figs. 2-4) were omitted. Similar positive correlations were observed with $\mathrm{SUVA}_{254}$, though only in HP4 was the correlation statistically significant $(r=0.69$, $n=10, p<0.05$ ) (Fig. 6). The second group of samples represented the time period from mid-April to October 2008 when the effect of previous irradiation (insolation) was potentially large. The correlation between $K$ and molecular weight was negative in PC1 $(r=-0.81, n=10, p<0.05)$ and DE5 ( $r=-0.69, n=10, p<0.05$ ) (Fig. 7); a negative correlation was also observed in HP4 but was not statistically significant. Similarly, a negative correlation was observed with $\mathrm{SUVA}_{254}$ (in PC1 $r=-0.77, n=10, p<0.05$, and in DE5 $r=-0.64, n=10, p<0.05$ ) (Fig. 7).

The observed increase in photodegradation rate constants during autumn and winter can be attributed to formation of new previously unexposed DOM derived from decomposition of terrestrial biomass and its subsequent transport to streams. The formation of fresh DOM is indicated by the increase in molecular weight and aromatic content determined as $\mathrm{SUVA}_{254}$.

\section{Factors affecting seasonal trends in photoreactivity}

\subsection{The effect of $\mathrm{pH}$}

The higher $\mathrm{pH}$ in HP4 samples was likely the reason for observed lower photodegradation rate constants. The effect of $\mathrm{pH}$ on photoreactivity has been documented elsewhere (i.e., Wang et al., 2000; Anesio and Granéli, 2003) as well the Dorset area in Ontario. Molot and Dillon (1997) determined lower photodegradation rate constants in HP4 compared to PC1 in summer 1995 under natural solar radiation. Gennings et al. (2001) measured photodegradation rate constants in PC1, HP4 and DE5 under natural solar radiation in summer 1997 and observed lower values for HP4 than in more acidic PC1 and DE5. Molot et al. (2005) exposed samples from DE5 to solar radiation and observed an increase in photodegradation rate constants with decreasing $\mathrm{pH}$ attributable in part to lower production of hydroxyl radicals with increasing $\mathrm{pH}$.

\subsection{Effect of $\mathrm{pH}$ and Fe concentration}

The major source of DOM in stream water is soil organic matter. Depending on complexing properties of soil organic matter, $\mathrm{pH}$, and other conditions, soil organic matter is able to dissolve and bind metals, and export them from terrestrial to 

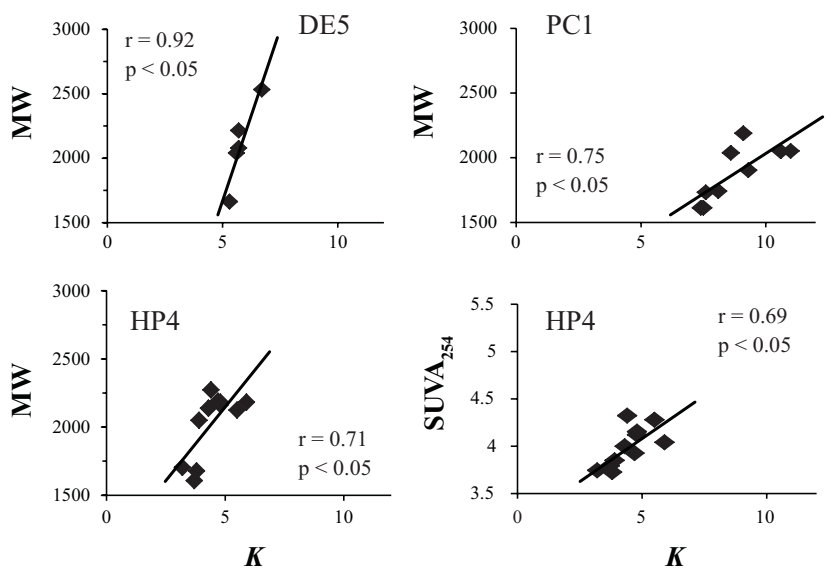

Fig. 6. Correlations between photodegradation rate constant, $K\left(\mathrm{~m}^{2} \mathrm{GJ}^{-1}\right)$, molecular weight, $M_{\mathrm{W}}(\mathrm{Da})$, and $\mathrm{SUVA}_{254}$ $\left(\mathrm{m}^{-1} \mathrm{mg}^{-1} \mathrm{~L}\right)$ in DE5, PC1 and HP4 streams during winter months when the catchments were snow covered.

aquatic systems (Mantoura et al., 1978; Vance et al., 1996). It has been shown that elevated $\mathrm{Fe}$ concentration enhances DOM photobleaching and photodegradation via the photoFenton pathway (Brinkmann et al., 2003; Gao and Zepp, 1998; Bertilsson and Tranvik, 2000), although this effect is negligible above $\mathrm{pH}$ 6. The relationship between photodegradation rate constant, $\mathrm{pH}$ and $\mathrm{Fe}$ concentration was studied by irradiating PC1 stream water in a solar simulator with initial DOC concentration of $16.8 \mathrm{mg} \mathrm{L}^{-1}$ and altering initial $\mathrm{pH}$ between 4.4 and 5.2 and $\mathrm{Fe}$ concentration between 6.4 and $10.4 \mathrm{mg} \mathrm{L}^{-1}$. A strong regression was found (P. Porcal, unpublished data, 2013):

$K=-2.38 \mathrm{pH}+0.59 \mathrm{Fe}+14.71$;

$\left(n=9, R^{2}=0.78, p=0.008\right)$.

Hence, some of the seasonal variation in $K$ may have been due to variation in $\mathrm{pH}$ and $\mathrm{Fe}$.

\subsection{Previous exposure to solar radiation}

A comparison of autumn and winter to summer samples with similar DOC concentration showed that summer samples had lower photodegradation rate constants than autumn and winter samples (paired $t$ test, $p<0.001$ ). Molecular weight and SUVA $_{254}$ were higher in summer than in autumn and winter samples, but the summer photodegradation rate constant did not increase with increasing molecular weight and $\mathrm{SUVA}_{254}$ as was observed during autumn and winter. These results show that winter and summer DOM are qualitatively different. While this difference may have been due to seasonal differences in DOM processing before export as well as $\mathrm{pH}$ and $\mathrm{Fe}$, it could also have been caused while traveling downstream to the sample collection site by aquatic processes that operate in the summer at greater rates than they do in the winter, for example, microbial consumption (Mulholland and
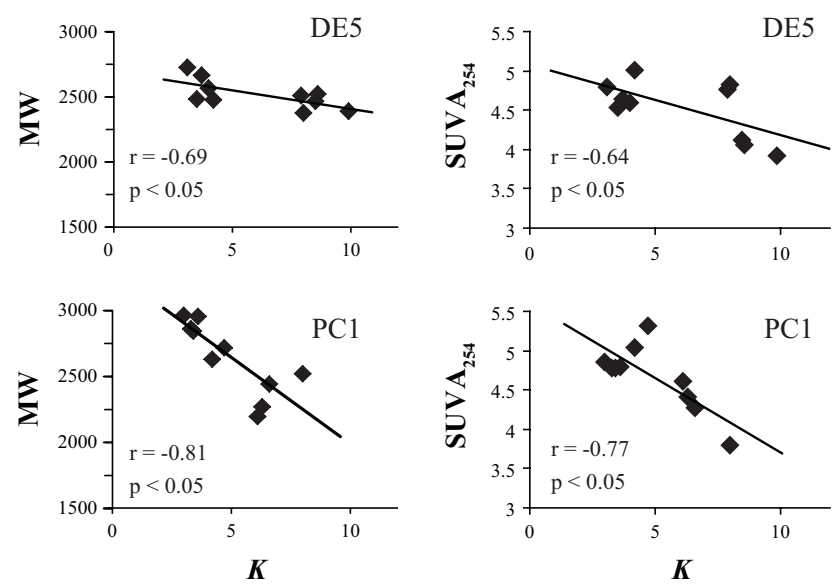

Fig. 7. Correlations between photodegradation rate constant, $K\left(\mathrm{~m}^{2} \mathrm{GJ}^{-1}\right)$, molecular weight, $M_{\mathrm{W}}(\mathrm{Da})$, and $\mathrm{SUVA}_{254}$ $\left(\mathrm{m}^{-1} \mathrm{mg}^{-1} \mathrm{~L}\right)$ in DE5 and PC1 streams during spring and summer months.

Hill, 1997) and photodegradation. Exposure to solar radiation en route in summer could destroy some of the more photosensitive organic compounds.

The effect of previous exposure of DOM to radiation on decreasing photoreactivity has been observed in streams, lakes and estuaries (i.e., Salonen and Vähätalo, 1994; Vähätalo et al., 2000; Twardowski and Donaghay, 2002). Porcal et al. (2010) measured photodegradation rate constants in first-order streams in Maine and observed their decline along a water pathway. Similar declines in photodegradation rate constants were observed in a Swedish forested catchment where the photodegradation rate constants were higher in soil water than in streams draining the same catchment (Köhler et al., 2002). It is reasonable to assume that DOM collected from the mouth of the study streams was exposed to some solar radiation during its in-stream surface transport through the catchment, and this previous exposure could contribute to the observed lower photodegradation rate constants in late spring and summer. Pooled $K$ data were weakly and negatively correlated with averaged solar insolation at the time of sample collection. For better clarification of the effect of previous irradiation (insolation) on photodegradation rate constants, we divided samples into three groups. In the autumn group (September, October, November and December) the correlation was -0.36 $(n=34, p<0.05)$; in winter (January, February and March) the correlation between photodegradation rate constants and insolation was not calculated because the catchments were covered by snow and insolation likely had a very small effect. In the spring/summer group (April-August) the correlation was stronger at $-0.59(n=32, p<0.05)$.

The effect of previous irradiation (insolation) is supported by different correlations between photodegradation rate constants and molecular weight and SUVA $_{254}$ (Figs. 8 and 9). 
The positive correlations between winter photodegradation rate constant, $K$, and molecular weight and $\mathrm{SUVA}_{254}$ support the notion that fresher DOM, having higher molecular weight and higher aromatic content $\left(\mathrm{SUVA}_{254}\right)$, easily undergoes photodegradation. In contrast, the correlation between $K$ and molecular weight and $\mathrm{SUVA}_{254}$ in summer months was negative and remains unexplained. Higher Fe levels in the summer might contribute to apparent $\mathrm{SUVA}_{254}$ remaining high after the melt period was over because of $\mathrm{Fe}$ absorbance in the UVC spectrum. The higher average molecular weight in summer might be attributable to coagulating metals resulting from a loss of metal binding sites via photodegradation (Porcal et al. 2013).

The increase in photodegradation rate constants during autumn and winter was likely driven by terrestrial production of fresh organic matter followed by humification as documented by the increase in molecular weight and $\mathrm{SUVA}_{254}$. The spring peak in photodegradation rate constants corresponded to spring snowmelt, when DOC concentrations decrease with increasing flow, a typical trend confirmed by a more than twenty years of data on seasonal trends in DOC concentrations in PC1 and HP4 (Eimers et al., 2008). This seasonal pattern is typical for wetland-dominated catchments where the DOC concentrations decline during peak flow (Laudon et al., 2004). The short-lived decrease in SUVA 254 following the high discharge in spring suggests that DOM may originate from different soil horizons in winter and summer. The decrease in photodegradation rate constants during late spring and summer may be driven by previous exposure of DOM to solar radiation during its pathway through the catchment, microbially mediated changes to DOM while in transit, and contributions of non-photoreactive DOM by aquatic primary producers to the DOM pool.

\section{Importance of photochemical properties - conclusions}

Molot and Dillon (1997) found that annual losses of DOM in Boreal lakes derived from short-term photodegradation experiments with in-coming stream waters could account for annual losses estimated from mass balances. Their estimates were based on photodegradation rate constants of samples collected and irradiated under natural radiation in summer and assumed that photodegradation rate constants were stable during the ice-free period. Our results found significant differences in photochemical properties during the hydrological year at all sampling locations. Significantly higher photodegradation rate constants were observed in spring than in summer; hence, Molot and Dillon's earlier annual loss estimates are low.

The observed seasonal cycle in photochemical properties of DOM suggests strong relationships between its terrestrial sources and hydrological processes within catchments. The significance of higher photodegradation rate constants in spring is enhanced by the fact that a large proportion of the annual DOC flux occurs at this time. In the twenty year period from 1980 to 2001, the average spring flux was $54 \%$ of the annual DOC fluxes at PC1 (Eimers et al., 2008). However, the potential importance of this season on DOM cycling in lakes is tempered by spring turnover, which mixes meltwater into deeper water where UV penetration is limited. Residence time of new stream inflows in upper waters receiving UVB and UVA increases with the onset of stratification, and the potential for DOM photodegradation will increase despite the fact that solar radiation is not high in northern latitudes in early spring. Lower photodegradation rate constants measured in summer at all sites indicates the importance of photodegradation of DOM while in transit to lakes despite the reduced solar insolation by forest canopy (Frost et al., 2005).

Acknowledgements. Thanks to Lance Aspden and Christiane Guay for sampling, and Heather Broadbent, Madalyn Budd, Mary Kingdon, and Martina Porcalová for lab assistance. This research was made possible by an NSERC Strategic Grant and by the Czech Science Foundation project P503/12/0781.

Edited by: T. J. Battin

\section{References}

Anesio, A. M. and Granéli, W.: Increased photoreactivity of DOC by acidification: Implications for the carbon cycle in humic lakes, Limnol. Oceanogr., 48, 735-744, 2003.

Bertilsson, S. and Tranvik, L. J.: Photochemical transformation of dissolved organic matter in lakes, Limnol. Oceanogr., 45, 753762,2000

Brinkmann, T., Sartorius, D., and Frimmel, F. H.: Photobleaching of humic rich dissolved organic matter, Aquat. Sci., 65, 415-424, 2003.

Brooks, M. L., McKnight, D. M., and Clements, W. H.: Photochemical control of copper complexation by dissolved organic matter in Rocky Mountain streams, Colorado, Limnol. Oceanogr., 52, 766-779, 2007.

Brown, A. M.: A step-by-step guide to non-linear regression analysis of experimental data using a Microsoft Excel spreadsheet, Comput. Meth. Prog. Bio., 65, 191-200, 2001.

Cabaniss, S. E., Madey, G., Leff, L., Maurice, P. A., and Wetzel, R.: A stochastic model for the synthesis and degradation of natural organic matter. Part I. Data structures and reaction kinetics, Biogeochemistry, 76, 319-347, 2005.

Chin, Y. P., Aiken, G., and O'Loughlin, E.: Molecular Weight, Polydispersity, and Spectroscopic Properties of Aquatic Humic Substances, Environ. Sci. Technol., 28, 1853-1858, 1994.

Devito, K. J. and Dillon, P. J.: Importance of runoff and winter anoxia to the $\mathrm{P}$ and $\mathrm{N}$ dynamics of a beaver pond, Can. J. Fish. Aquat. Sci., 50, 2222-2234, 1993.

Dillon, P. J. and Molot, L. A.: Dissolved organic and inorganic carbon mass balances in central Ontario lakes, Biogeochemistry, 36, 29-42, 1997a. 
Dillon, P. J. and Molot, L. A.: Effect of landscape form on export of dissolved organic carbon, iron, and phosphorus from forested stream catchments, Water Resour. Res., 33, 2591-2600, $1997 \mathrm{~b}$.

Dillon, P. J., Molot, L. A., and Scheider, W. A.: Phosphorus and Nitrogen Export from Forested Stream Catchments in Central Ontario, J. Environ. Qual., 20, 857-864, 1991.

Eimers, M. C., Buttle, J. and Watmough, S. A.: Influence of seasonal changes in runoff and extreme events on dissolved organic carbon trends in wetland- and upland-draining streams, Can. J. Fish. Aquat. Sci., 65, 796-808, 2008.

Escobedo, J. F., Gomes, E. N., Oliveira, A. P., and Soares, J.: Ratios of UV, PAR and NIR components to global solar radiation measured at Botucatu site in Brazil, Renew. Energ., 1, 169-178, doi:10.1016/j.renene.2010.06.018, 2011.

Freeman, C., Fenner, N., Ostle, N. J., Kang, H., Dowrick, D. J., Reynolds, B., Lock, M. A., Sleep, D., Hughes, S., and Hudson, J.: Export of dissolved organic carbon from peatlands under elevated carbon dioxide levels, Nature, 430, 195-198, 2004.

Frost, P. C., Larson, J. H., Kinsman, L. E., and Bridgham, S. D.: Attenuation of ultraviolet radiation in streams of northern Michigan, J. N. Am. Benthol. Soc., 24, 246-255, 2005.

Gao, H. and Zepp, R. G.: Factors Influencing Photoreactions of Dissolved Organic Matter in a Coastal River of the Southeastern United States, Environ. Sci. Technol., 32, 2940-2946, 1998

Gennings, C., Molot, L. A., and Dillon, P. J.: Enhanced photochemical loss of organic carbon in acidic waters, Biogeochemistry, 52, 339-354, 2001.

Glaeser, J., Nuss, A. M., Berghoff, B. A., and Klug, G.: Singlet Oxygen Stress in Microorganisms, Adv. Microb. Physiol., 58, 141173,2011

Granéli, W., Lindell, M., and Tranvik, L.: Photo-oxidative production of dissolved inorganic carbon in lakes of different humic content, Limnol. Oceanogr., 41, 698-706, 1996.

Köhler, S., Buffam, I., Jonsson, A., and Bishop, K.: Photochemical and microbial processing of stream and soil water dissolved organic matter in a boreal forested catchment in northern Sweden, Aquat. Sci., 64, 269-281, 2002.

Kothawala, D., Evans, R. D., and Dillon, P. J.: Changes in the molecular weight distribution of dissolved organic carbon within a Precambrian Shield stream, Water Resour. Res., 42, W05401, doi:10.1029/2005WR004441, 2006.

Laudon, H., Köhler, S., and Buffam, I.: Seasonal TOC export from seven boreal catchments in northern Sweden, Aquat. Sci., 66, 223-230, 2004.

Lindell, M. J., Granéli, H. W., and Bertilsson, S.: Seasonal photoreactivity of dissolved organic matter from lakes with contrasting humic content, Can. J. Fish. Aquat. Sci., 57, 875-885, 2000.

Mantoura, R. F. C., Dickson, A., and Riley, J. P.: The complexation of metals with humic materials in natural waters, Estuar. Coast. Mar. Sci., 6, 387-408, 1978.

Miller, W. L. and Moran, M. A.: Interaction of photochemical and microbial processes in the degradation of refractory dissolved organic matter from a coastal marine environment, Limnol. Oceanogr., 42, 1317-1324, 1997.

Molot, L. A. and Dillon, P. J.: Photolytic regulation of dissolved organic carbon in northern lakes, Global Biochem. Cy., 11, 351$365,1997$.

Molot, L. A., Hudson, J. J., Dillon, P. J., and Miller, S. A.: Effect of $\mathrm{pH}$ on photo-oxidation of dissolved organic carbon by hydroxyl radicals in a coloured, softwater stream, Aquat. Sci., 67, 189195, 2005.

Mulholland, P. J. and Hill, W. R.: Seasonal patterns in streamwater nutrient and dissolved organic carbon concentrations: Separating catchment flow path and in-stream effects, Water Resour. Res., 33, 1297-1306, 1997.

Perdue, E. M.: Chemical composition, structure, and metal binding properties, in: Aquatic humic substances, edited by: Hessen, D. O. and Tranvik, L. J., Springer-Verlag, Berlin Heidelberg, 41-61, 1998.

Petty, G. W.: A first course in atmospheric radiation, 2nd Edn., Sundog Publishing, Madison, Wisconsin, USA, 2006.

Porcal, P., Hejzlar, J., and Kopáček, J.: Seasonal and photochemical changes of DOM in an acidified forest lake and its tributaries, Aquat. Sci., 66, 211-222, 2004.

Porcal, P., Koprivnjak, J. F., Molot, L. A., and Dillon, P. J.: Humic substances - part 7: the biogeochemistry of dissolved organic carbon and its interactions with climate change, Environ. Sci. Pollut. Res., 16, 714-726, 2009.

Porcal, P., Amirbahman, A., Kopáček, J., and Norton, S. A.: Experimental photochemical release of organically bound aluminum and iron in three streams in Maine, USA, Environ. Monit. Assess., 171, 71-81, doi:10.1007/s10661-010-1529-x, 2010.

Porcal, P., Dillon, P. J., and Molot, L. A.: Photochemical production and decomposition of particulate organic carbon in a freshwater stream, Aquat. Sci., doi:10.1007/s00027-013-0293-8, 2013.

Ruiz-Gonzáles, C., Simó, R., Sommaruga, R., and Gasol, J. M.: Away from darkness: A review on the effects of solar radiation on heterotrophic bacterioplankron activity, Front. Microbiol., 4, doi:10.3389/fmicb.2013.00131, 2013

Salonen, K. and Vähätalo, A.: Photochemical mineralisation of dissolved organic matter in Lake Skervatjern, Environ. Int., 20, $307-$ 312, 1994.

Scully, N. M., Cooper, W. J., and Tranvik, L. J.: Photochemical effects on microbial activity in natural waters: the interaction of reactive oxygen species and dissolved organic matter, FEMS Microbiol. Ecol., 46, 353-357, 2003

Suhett, A. L., Amado, A. M., Enrich-Prast, A., de Assis, E. F., and Farjalla, V. F.: Seasonla changes of dissolved organic carbon photo-oxidation rates in a tropical humic lagoon: the role of rainfall as a major regulator, Can. J. Fish. Aquat. Sci., 64, 12661272, 2007.

Twardowski, M. S. and Donaghay, P. L.: Photobleaching of aquatic dissolved materials: Absorption removal, spectral alteration, and their interrelationship, J. Geophys. Res., 107, 3091, doi:10.1029/1999JC000281, 2002.

Vähätalo, A., Salkinoja-Salonen, M., Taalas, P., and Salonen, K.: Spectrum of the quantum yield for photochemical mineralization of dissolved organic carbon in a humic lake, Limnol. Oceanogr., 45, 664-676, 2000.

Vance, G. F., Stevenson, F. J., and Sikora, F. J.: Environmental chemistry of aluminum-organic complexes, in: The environmental chemistry of aluminum, edited by: Sposito, G., Lewis Publishers, Chelsea, 169-220, 1996.

Von Wachenfeldt, E., Sobek, S., Bastviken, D., and Tranvik, L. J.: Linking allochthonous dissolved organic matter and boreal lake sediment carbon sequestration: The role of light-mediated flocculation, Limnol. Oceanogr., 53, 2416-2426, 2008. 
Vuorenmaa, J., Forsius, M., and Mannio, J.: Increasing trends of total organic carbon concentrations in small forest lakes in Finland from 1987 to 2003, Sci. Total Environ., 365, 47-65, 2006.

Wang, W., Tarr, M. A., Bianchi, T. S., and Engelhaupt, E.: Ammonium Photoproduction from Aquatic Humic and Colloidal Matter, Aquat. Geochem., 6, 275-292, 2000.

Weishaar, J. L., Aiken, G. R., Bergamashi, B. A., Fram, M. R., Fujii, R., and Mopper, K.: Evaluation of Specific Ultraviolet Absorbance as an Indicator of the Chemical Composition and Reactivity of Dissolved Organic Carbon, Environ. Sci. Technol., 37, 4702-4708, 2003.

Wetzel, R. G., Hatcher, P. G., and Bianchi, T. S.: Natural photolysis by ultraviolet irradiance of recalcitrant dissolved organic matter to simple substrates for rapid bacterial metabolism, Limnol. Oceanogr., 40, 1369-1380, 1995.
Worrall, F., Harriman, R., Evans, C. D., Watts, C. D., Adamson, J., Neal, C., Tipping, E., Burt, T., Grieve, I., Monteith, D., Naden, P. S., Nisbet, T., Reynolds, B., and Stevens, P.: Review of riverine DOC trends in the UK, Biogeochemistry, 70, 369-402, 2004.

Wu, F. C., Evans, R. D., and Dillon, P. J.: Separation and Characterization of NOM by High-Performance Liquid Chromatography and On-Line Three-Dimensional Excitation Emission Matrix Fluorescence Detection, Environ. Sci. Technol., 37, 36873693, 2003.

Zepp, R. G., Wolfe, N. L., Baughman, G. L., and Hollis, R. C.: Singlet oxygen in natural waters, Nature, 267, 421-423, 1977. 